\title{
Office Noise and employee Productivity (Chandigarh)
}

\author{
Gurkirpal Singh \\ Phd Research Scholar, Punjab Technical University, Jalandhar, INDIA,
}

\begin{abstract}
Organizations spend maximum on staff salaries. The staff should be productive in order to be efficient and competitive in the profession..Staff will be productive when they are comfortable with regard to Office Environment. In this study influence of Noise on productivity of office occupants is highlighted. A research as fulfillment for Phd degree under Punjab Technical University-Jalandhar, to this regard was conducted in Offices of capital city of Chandigarh(India). Various Offices at Chandigarh were sampled and Questionnaire survey of productivity was conducted to get first hand information from Office Occupants. Keywords: Noise, productivity, office design
\end{abstract}

\section{Introduction}

People spend most of their time indoors -- be it office or home. The efficiency of any organization is influenced by the productivity of the employees. The productivity of the employees is dependent on comfort levels at their office. World over research has been done to study the effect on office noise/environment on productivity of office inhabitants but not in India. So the present research study as fulfillment for Phd degree under Punjab Technical University- Jalandhar, to this regard is conducted to identify the effects of office noise in offices at Chandigarh (India).

Aim is to study the effect on productivity of office employees of noise.

Literature review Various literature pertain to the study of multiple offices and office buildings indicated that the factors such as dissatisfaction, cluttered workplaces and the physical environment are playing a major role in the loss of employees' productivity (Carnevale 1992, Clements-Croome 1997).

How workspace is designed and occupied affects not only how people feel, but also their work performance, their commitment to their employer, and the creation of new knowledge (human capital) in the organization. These are the cornerstones of the domain known as the environmental psychology of workspace (Vischer, 2008). Moreover, measures of user perceptions of environmental conditions can be used to diagnose building performance and the effectiveness of building systems (Vischer \& Fischer, 2005).A large number of work environment studies have tested users' satisfaction in reference to specific workspace features(Becker, 1981; Brennan, Chugh \& Kline, 2002; Hedge, 1991;Humphries, 2005; Veitch, Charles, Newsham, Marquardt \&Geerts, 2004). These studies show that people's preferences are affected by, among other things, Noise.

Sample

\section{Methodology}

A total of 660 employees from various offices of Chandigarh were recruited as sample. The age range of the sample was between 25-60 years. The minimum educational qualification was graduation. For inclusion in the study the employee must be working in that particular organization since last three years. Primary data was collected through a structured questionnaire. The questionnaire was developed on the basis of the research literature review. The questionnaire consisted of 5 questions on noise variable to be rated on a five point Likert scale.

\section{Data Analysis}

For result findings and in-depth analysis of the different components of office environment on the performance level of the employees, statistical techniques of correlation has been used. SPSS software as research tool for data analysis is used for this research.

\section{Results}

Table 1: Descriptive Statistic of Various Factors/Elements of Office Design

\begin{tabular}{|l|l|l|l|}
\hline Factors & Respondents $(\mathbf{N})$ & Mean & Std. Deviation \\
\hline Noise & 660 & 2.9723 & .57606 \\
\hline
\end{tabular}


Table 2: Correlation between Elements of Office Design and Employee Productivity

\begin{tabular}{|l|l|l|}
\hline Office Design Element & Pearson Correlation $(\mathbf{r})$ & Significance \\
\hline Noise & $.350^{* *}$ & .00 \\
\hline
\end{tabular}

** Correlation is significant at the 0.01 level (2-tailed)

\section{Result analysis}

This relationship between office design and productivity was determined by using the Pearson's Correlation. This shows that when the Noise of the office is not comfortable and according to the needs of the employees their productivity is affected. The positive relationship between Noise and productivity $(\mathrm{r}=.350)$ at 0.00 shows that employees' productivity correlates to the Noise conditions in the offices.(Table 2).

\section{Discussion}

Analysis of the collected data revealed that office design has a substantial impact on the employees' productivity. The overall impact of different elements showed that Noise affects the productivity of most employees. The results are similar to previous research viz;Amjad\& Hamid (2009), Amir \&Shahibzada (2009); Haapakangas et al (2008), Kari (2010), Miller et al (2010); Vischer, (2005), Wyon (2004).

Present research study as fulfillment for Phd degree under Punjab Technical University- Jalandhar, to this regard found correlation between employee's productivity and Noise. Tapping Noise as a resource reduces energy use and improves productivity.

Limitations the study is limited to Noise only and is not exhaustive .

Following are a few limitations of the study-- The sample size was not diverse enough to give the image of all organizations functioning in India.

\section{Future Research Scope}

Future research can be done on the public sector or semi government organizations and can be compared with the findings of this research. In addition a good study can be conducted for comparison among services and manufacturing sector as well.

\section{Conclusion}

On the basis of our research we can conclude that the Noise component of office environment have impact on the performance level of the office employees, can affect the out put of the employees. If Noise factor is favorable for office employees then they can perform much better. This will contribute towards enhanced output and exceptional performance

\section{References}

[1]. Huges, J. (2007, July). Office design is pivotal to employee productivity. Sandiego source the daily transcript.

[2]. The Gensler Design + Performance Index, The U.S. Workplace Survey (2006), www.gensler.com

[3]. Clements-Croome, D., Kaluarachchi, Y. (2000) An Assessment of the Influence of the In-door Environment on the Productivity of Occupants in Offices Design, Construction and Operation of Healthy Buildings ,pp.67-81

[4]. Roelofsen, P. (2002). The impact of office environments on employee performance: The design of the workplace as a strategy for productivity enhancement. Journal of Facilities Management, 1(3), 247-264.

[5]. Haynes, B. P. (2007). Office productivity: A shift from cost reduction to human contribution. Facilities, 25(11/12), 452-462.

[6]. Hameed, A., \&Amjad, S. (2009). „Impact of office design on employeese productivity: A case study of banking organizations of Abbottabad, Pakistan. Journal of Public Affairs, Administration and Management, 3(1), 1-13.

[7]. Perceived acoustic environment, work performance and well-being -survey results from Finnish offices -- AnnuHaapakangas, RiikkaHelenius, EskoKeskinen, ValtteriHongisto

[8]. Measuring the impact of office environment on performance level of employees in the private sector of pakistan--Faiza Amir \& Dr. Shamim A Sahibzada; Shaheed Zulfiqar Ali Bhutto Institute of Science and Technology Islamabad Pakistan .Faculty of Management Sciences

[9]. Journal of public affairs, administration and management Volume 3, Issue 1, 2009; Impact of Office Design on Employees' Productivity: A Case study of Banking,Organizations of Abbottabad, Pakistan ;AminaHameed, ShehlaAmjad,

[10]. Faculty of Business and EconomicsThe English Language PhD Programme The impact of the indoor environment on the productivity of Call Center Employees By Uri Domàn Submitted for the Degree of Doctor of Philosophy

[11]. Green Buildings and Productivity Draft: August 19, 2009Forthcoming in the Journal of Sustainable Real Estate Vol. 1, No. 1, Fall 2009

[12]. By Norm G. Miller, PhD, University of San Diego, Burnham-Moores Center for Real Estate[nmiller@sandiego.edu] and Dave Pogue, LEED AP and National Director of Sustainability, CBRE [Dave.Pogue@ cbre.com]

[13]. Quiana D. Gough, University of Baltimore, degree expected May of 2010 in Business,quianagough@comcast.net and Susan M. Davis, Bachelor of Commerce, University of British Columbia,susan.marie.davis@ gmail.com

[14]. Vischer, J.C. (2005). Measuring the Impact of Moving on Building Users. EcoLibrium. September, 22-27.

[15]. Carnevale, D.G., (1992), Physical Settings of Work. Public Productivity and Management Review, 15, 4,sd423-436.

[16]. Clements-Croome, D.J., (1997). Specifying Indoor Climate, in book Naturally Ventilated Buildings, (Spon)

[17]. Sehgal S. (2012) "Relationship between Work Enviornment And Productivity" International Journal of Engineering Research and Applications. Vol. 2, (4),1992-1995. 